\title{
Evaluation of Antifungal Efficacy of Selected Microorganisms Against Apple Rot Pathogens
}

\author{
Neelam Kumari ${ }^{{ }^{*}}$, J. N. Sharma ${ }^{2}$ and Deepika Singh ${ }^{3}$ \\ ${ }^{1,2}$ Dept. of Plant Pathology, ${ }^{3}$ Dept. of Fruit Science, Dr. Y. S. Parmar University of Horticulture and Forestry, Nauni, Solan, \\ H.P. (173 230), India
}

\section{Corresponding Author}

Neelam Kumari

e-mail: neelkumari90@gmail.com

\author{
Article History \\ Article ID: IJEP0277 \\ Received in $20^{\text {th }}$ October, 2018 \\ Received in revised form $11^{\text {th }}$ November, 2018 \\ Accepted in final form $21^{\text {st }}$ November, 2018
}

\begin{abstract}
Biological control of post harvest pathogens of fruits and vegetables is an effective alternative to chemical based treatments because of its minimal impact on the environment and human health. The antifungal efficiency of antagonistic microorganisms occurring naturally on apple fruit surface (Trichoderma viride, T. hamatum, T. harzianum, Bacillus subtilis, Pseudomonas fluorescens and one yeast isolate) against post harvest pathogens of apple (Alternaria alternata, Monilinia fructigena, Trichothecium roseum, Aspergillus niger, Penicillium expansum) was evaluated both under in vitro and in vivo conditions. Overall maximum growth inhibition of all the test fungi (71.97\%) was reported with $T$. hamatum followed by the yeast isolate (66.63\%), B. subtilis (64.98\%) and T. harzianum (62.43\%).
\end{abstract}

Keywords: Apple, antagonistic microorganisms, biological control, in vitro, in vivo, post harvest

\section{Introduction}

Fruits and vegetables suffer from a number of fungal diseases after harvest. These losses in fruits and vegetables ranges from 10 to 40 per cent depending on the crop, variety and management practices adopted during crop growth. Among the different fungal pathogens, Alternaria alternata, Botrytis cinerea, Glomerella cingulata, Monilinia fructigena and Penicillium expansum are the dominant ones causing post harvest losses. Penicillium expansum Link causes the post harvest disease known as blue mould and is considered the most important disease of stored apples (Turechek, 2004). In most instances, the post harvest pathogens gain entry to susceptible fruit tissues and cause infection via entry through fruit's surface wounds that are generated through the process of harvesting and post harvest handling.

Traditionally, post harvest diseases are controlled by the application of synthetic fungicides. However, their harmful effects on environment as well as on human health limit their application. It is also reported that some pathogens have become fungicide resistant, thereby limiting the use of synthetic fungicides. Therefore, biological control has emerged as an alternative tool for the management of post harvest rots of fruits and vegetables. Besides having several advantages over synthetic fungicides, the rate of degradation of biopesticides is much faster and they are less toxic to nontarget organisms. Several commercial products originated from antagonists are available, such as Kodiak (B. subtilis strain
GB03), RhizoPlus (B. subtilis FZB24), TrichoVir ( $T$. viride) etc.

The aim of this study was to test the activity of selected microorganisms as potential antagonists against isolated strains of causal agents of apple fruit rot.

\section{Materials and Methods}

\subsection{Fungal pathogens}

Isolates of Alternaria alternata, Monilinia fructigena, Trichothecium roseum, Aspergillus niger and Penicillium expansum were obtained from apple fruit samples (cv. Starking Delicious) expressing rot symptoms. Apple fruit samples were collected during survey made during 2015 and 2016 from different markets/stores/godowns of Shimla and Solan districts of Himachal Pradesh. The pathogens were isolated using standard phytopathological techniques. The diseased fruits were surface sterilized with absolute alcohol under aseptic conditions. Small bits of 1 to $2 \mathrm{~mm}$ size were taken from junction of diseased and healthy part of fruit with the help of sterilized sharp blade and scalpel. These bits were surface sterilized with sodium hypochlorite (1.0\%) for 10 to 20 seconds and washed thrice with sterilized distilled water under aseptic conditions. The bits were then placed on the sterilized filter paper to remove the excess moisture and subsequently transferred to sterilized Petri plates containing potato dextrose agar (PDA) medium. The inoculated Petri plates were incubated at $25 \pm 1{ }^{\circ} \mathrm{C}$ in BOD incubator and examined daily for mycelial growth. The fungal growth developed in Petri 
plates was purified by hyphal tip technique and was further cultured on slants containing PDA. These slants of culture were preserved at $5{ }^{\circ} \mathrm{C}$ in the refrigerator for further studies. Stock cultures were maintained by regularly sub-culturing after 20 to 25 days.

The causal organisms were identified by studying their morphology and comparisons with standard authentic descriptions from literature (Marie-Jose et al., 2004; Al-Hindi, 2011; Jurick, 2014; Hamid et al., 2014; Vico et al., 2014).

\subsection{Antagonists}

Six antagonistic microorganisms (Trichoderma viride, $T$. hamatum, T. harzianum, Bacillus subtilis, Pseudomonas fluorescens and one yeast isolate) were isolated from the natural environment i.e. neglected apple orchard with minimal or no pesticide spray history.

Fruit samples irrespective of cultivar types were collected in the month of Aug and Sept from Shimla district of Himachal Pradesh. One gram of sample of fruit peel was taken in $25 \mathrm{ml}$ of sterilized distilled water in a mortar and macerated with the pestle. The extract was then vortexed briefly and $0.1 \mathrm{ml}$ serial dilution (0.10) of the extract was placed onto nutrient yeast extract dextrose agar (NYDA) and potato dextrose agar (PDA) medium in sterilized Petriplates. After $48 \mathrm{~h}$ of incubation at $25 \pm 0.5^{\circ} \mathrm{C}$, different colonies were picked and transferred to NYDA and PDA slants or media plates. They were further purified by streaking and/or hyphal tip method. The separated, purified colonies were tentatively grouped as fungi, bacteria and yeast.

Fungal isolates were identified on the basis of cultural and morphological characteristics. Bacterial isolates were identified on the basis of Gram staining. Yeast isolates were identified on the basis of microscopic examination and cultural characteristics.

\subsection{In vitro antagonistic activity assay}

Isolated fungal antagonists were tested for their antagonistic activities against test pathogens by dual culture method (Denis and Webster, 1971). Culture discs (3 mm diameter) of each of antagonists and the test pathogens were taken from margin of their vigorously growing culture and transferred aseptically to solidified PDA (Potato Dextrose Agar) medium contained in Petriplates $(90 \mathrm{~mm}$ ) on the opposite sides facing each other at a distance of $1 \mathrm{~cm}$ from the margin of the plate. The Petriplates containing only culture of the test pathogens served as control. The experiment was laid out in CRD and each treatment was replicated thrice and the Petriplates were incubated at $25 \pm 1^{\circ} \mathrm{C}$ in a BOD incubator. The colony diameter of test pathogens was recorded till the control plates achieved full growth of the test fungus and per cent inhibition was calculated by the formula given by Vincent (1947):

Where:

$$
\mathrm{I}=\frac{\mathrm{C}-\mathrm{T}}{\mathrm{C}} \times 100
$$

I=Per cent inhibition
$\mathrm{C}=$ Linear growth in control $(\mathrm{mm})$

$\mathrm{T}=$ Linear growth in treatment $(\mathrm{mm})$

The antagonistic activity of isolated bacteria and yeast against the test pathogens was studied by streak plate method (Utkhede and Rahe, 1983). The Petriplates containing sterilized PDA were streaked at the centre with 48 hours old colonies of bacteria/yeast with the help of inoculation needle. Mycelial bit ( $3 \mathrm{~mm}$ diameter) of the test pathogens were placed on opposite sides of the streak at a distance of $1 \mathrm{~cm}$ from the margin of the plate. The Petriplates containing only culture of the test pathogens served as control. Each treatment was replicated thrice under Completely Randomized Design (CRD) and incubated at $25 \pm 1{ }^{\circ} \mathrm{C}$ in BOD incubator. Per cent inhibition of the radial growth of test pathogens, if any, was calculated with the same formula as described above.

\subsection{In vivo antagonistic activity assay}

The Starking Delicious apple fruits were selected free of wounds and being homogeneous as much as possible in physiological maturity stage and size. Selected fruits were washed with sterile water and then air dried for 15-20 min. These fruits were then inoculated separately by well method of Granger and Horne (1924) with the test pathogens. Twelve hours after inoculation, fruits were dipped in effective fungal, bacterial and yeast inoculum. The inoculum was prepared and adjusted to the concentration of $10^{8} \mathrm{cfu} / \mathrm{ml}$ with water. Each treatment was replicated thrice containing five fruits per replicate for a particular test fungus. Untreated inoculated fruits were kept as control for comparison. Observation on per cent rotting of fruits was taken after 6 days of inoculation when the control fruits rotted completely. Per cent fruit rot was recorded by the formula given by Srivastava and Tandon (1968):

Per cent fruit rot $=\frac{W-W}{W} \times 100$

Where,

$W=$ weight of the fruits before inoculation

$w=$ weight of the fruits after removal of the rotten tissue

\section{Results and Discussion}

\subsection{In vitro antagonistic activity assay}

From the data presented in Table 1, it is clear that overall maximum growth inhibition $(71.97 \%)$ of all the test fungi was reported with $T$. hamatum followed by the yeast isolate (66.63\%), B. subtilis (64.98\%), T. harzianum (62.43\%) and $T$. viride $(60.31 \%)$. Least growth inhibition was observed with $P$. fluorescens (54.00\%). Irrespective of different biocontrol agents, maximum growth inhibition (88.93\%) was recorded in $M$. fructigena followed by $T$. roseum (66.14\%), A. niger (60.22\%), P. expansum (58.60\%) and A. alternata $(43.05 \%)$ (Figure 1).

From the interaction studies it is clear that mycelial growth of $M$. fructigena and $T$. roseum was significantly inhibited by all the biocontrol agents. T. hamatum provided maximum 


\begin{tabular}{|c|c|c|c|c|c|c|}
\hline \multirow[t]{2}{*}{ Antagonist } & \multicolumn{6}{|c|}{ Growth inhibition (\%) } \\
\hline & A. alternata & T. roseum & M. fructigena & A.niger & P. expansum & Mean \\
\hline T. viride & 43.27 & 77.07 & 91.33 & 21.95 & 67.94 & $60.31(50.93)$ \\
\hline T. hamatum & 46.83 & 81.74 & 87.23 & 77.51 & 66.56 & $71.97(58.01)$ \\
\hline T. harzianum & 25.93 & 31.61 & 93.93 & 72.65 & 88.06 & $62.43(52.18)$ \\
\hline P. fluorescens & 10.76 & 46.95 & 85.88 & 62.93 & 63.50 & $54.00(47.28)$ \\
\hline B. subtilis & 64.53 & 75.60 & 82.49 & 61.66 & 40.59 & $64.98(53.70)$ \\
\hline Yeast & 67.01 & 83.87 & 92.70 & 64.62 & 24.96 & $66.63(54.69)$ \\
\hline Mean & 43.05 (40.99) & 66.14 (4.39) & 88.93 (70.54) & $60.22(50.88)$ & $58.60(49.93)$ & \\
\hline
\end{tabular}
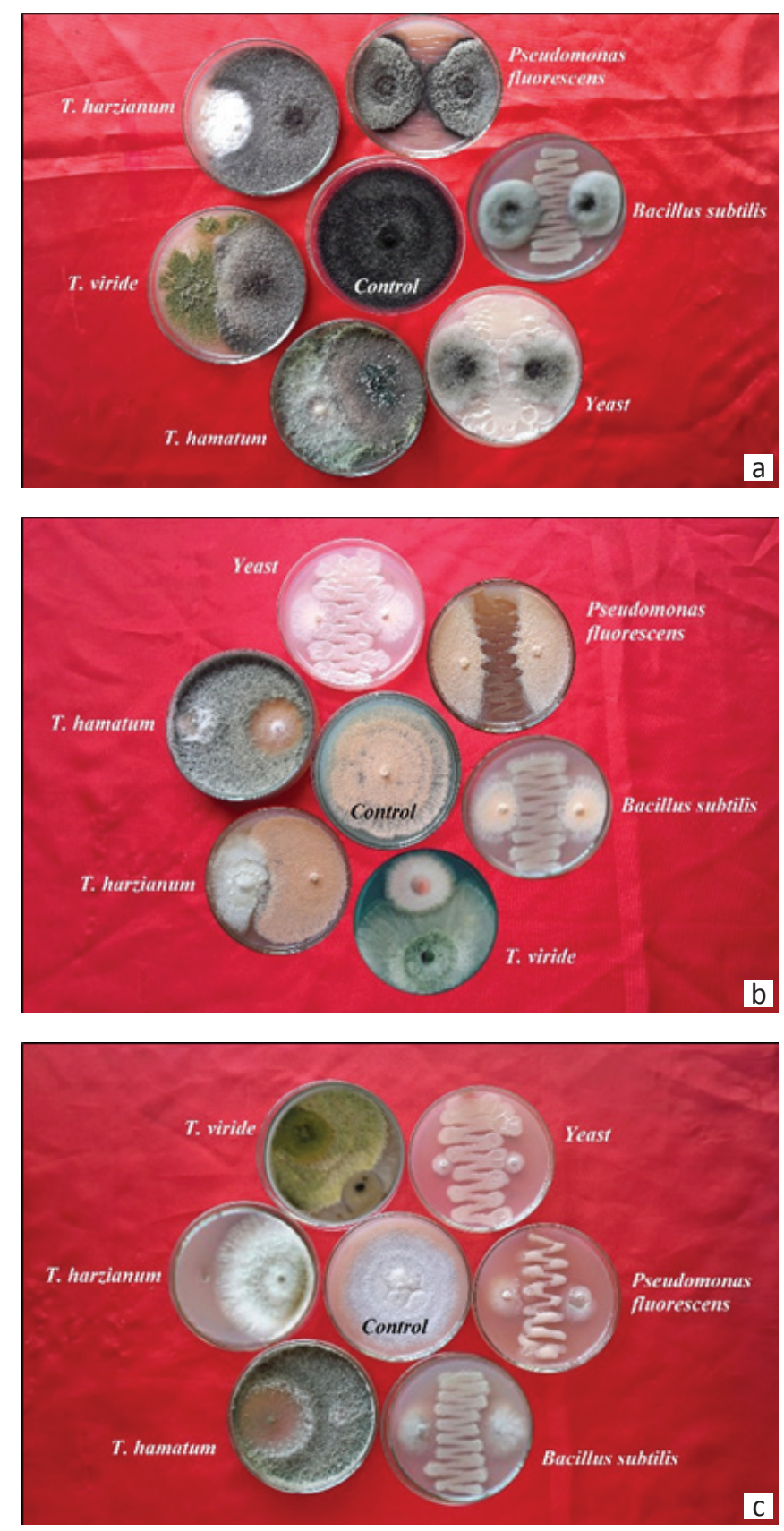

C
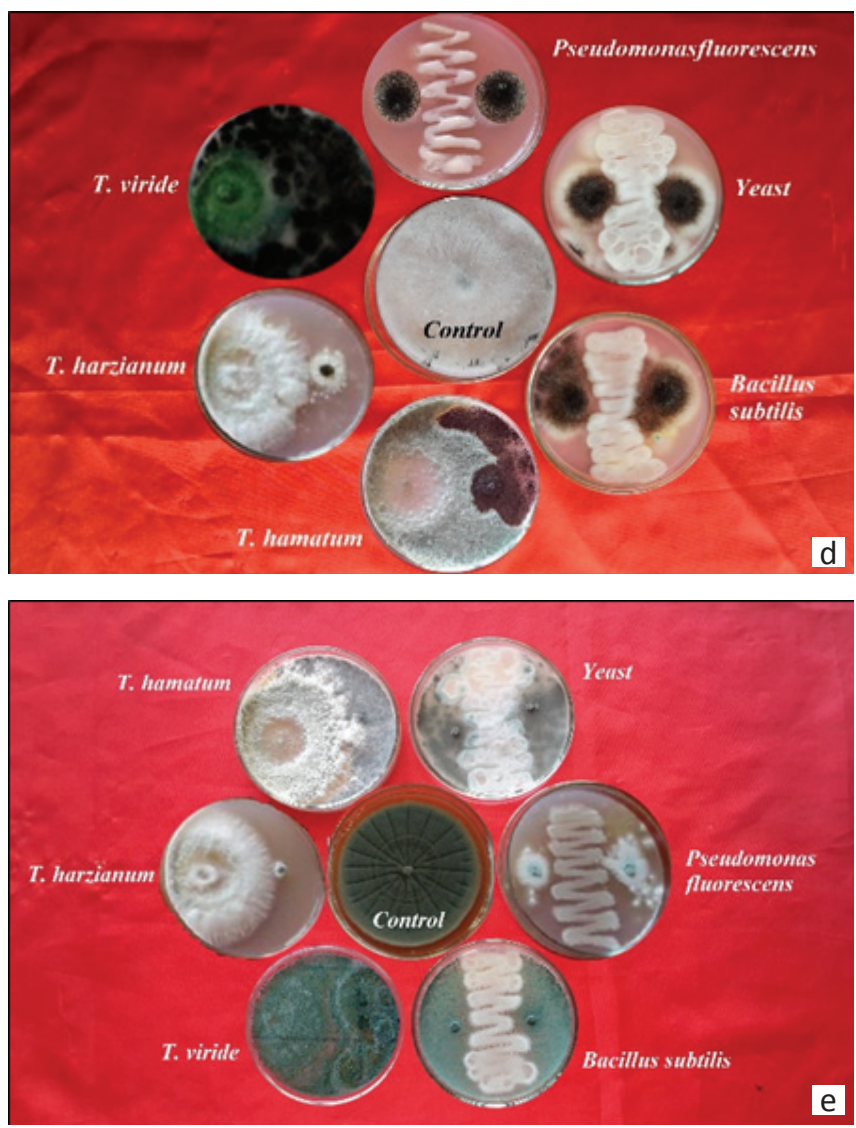

Figure 1: In vitro evaluation of antagonists against Alternaria alternata (a), Trichothecium roseum (b), Monilinia fructigena (c), Aspergillus niger (d) and Penicillium expansum (e)

inhibition of all the test fungi under study. Next effective antagonist was the yeast isolate which was found effective against all the test fungi except $P$. expansum. Among bacterial antagonists, $B$. subtilis was more effective than $P$. fluorescens. The reports available on the mechanism of the biocontrol of post harvested commodities suggest that competition for nutrients and space plays a major role in most cases (Wisniewski et al., 1991; Calvente et al., 1999). Many other yeasts, viz. Clonostachys rosea, Candida saitoana, Cystofilobasidium infirmominiatum, Rhodosporidium

$\varnothing$ 
paludigenum, Pichia caribbica, P. fermentans, P. guilliermondii and $P$. membranifaciens have been found effective against various post harvest rot causing pathogens of fruits (ElGhaouth et al., 2003; Chan et al., 2007; Liu et al., 2011; Fiori et al., 2012; Wang et al., 2010; Xu et al., 2013).

\subsection{In vivo antagonistic activity assay}

The biocontrol agents screened under in vitro conditions for their effectiveness against post harvest pathogens of apple fruits were further evaluated under in vivo conditions and data obtained on per cent fruit rot has been presented in Table 2. From the perusal of data it is clear that T. hamatum provided maximum control $(80.69 \%)$ of all the test fungi under study followed by the yeast isolate (76.29\%). Other effective biocontrol agents in the order of merit were $B$. subtilis (68.55\%), T. harzianum (65.02\%) and T. viride (61.66\%). $P$. fluorescens was least effective among all the biocontrol agents.
The cumulative reaction of various test fungi towards differently treated fruits showed maximum rotting due to $P$. expansum (43.43\%) followed by $A$. alternata $(42.95 \%), M$. fructigena (42.85\%), A. niger (42.05\%) and T. roseum (41.20\%). The interaction studies between biocontrol agents and test fungi revealed that none of the biocontrol agent provided complete control of any of the test fungi in vivo. However, significant disease control of all the test fungi in comparison to control was achieved with T. hamatum (80.69\%) and the yeast isolate (76.29\%).

Many recent studies have demonstrated the effect of various Trichoderma species on post harvest rot diseases caused by many fungal pathogens (Odebode, 2006; Patale and Mukadam, 2011; Hafez et al., 2013). T. harzianum has been used to control the fungal diseases caused by A. alternata, $P$. expansum (blue mould on apples), Botrytis cinerea (grey mould on apples) and Rhizoctonia sp. (Agrios, 1997; Batta,

\begin{tabular}{lccccccc}
\hline \multicolumn{7}{l}{ Table 2: Effect of biocontrol agents against post harvest rotting of apple cv. Starking Delicious } \\
\hline Antagonist & \multicolumn{7}{c}{ Growth inhibition (\%) } \\
\cline { 2 - 7 } & A. alternata & T. roseum & M. fructigena & A.niger & P. expansum & Mean & Per cent control \\
\hline T. viride & 36.99 & 38.06 & 40.44 & 36.00 & 40.19 & $38.34(38.24)$ & 61.66 \\
T. hamatum & 23.33 & 15.67 & 18.17 & 20.44 & 18.92 & $19.31(26.06)$ & 80.69 \\
T. harzianum & 34.07 & 35.22 & 37.78 & 31.77 & 36.07 & $34.98(36.24)$ & 65.02 \\
P. fluorescens & 45.66 & 47.06 & 46.88 & 53.77 & 55.07 & $49.69(44.80)$ & 50.31 \\
B. subtilis & 31.66 & 32.67 & 34.00 & 28.82 & 30.12 & $31.45(34.10)$ & 68.55 \\
Yeast & 28.93 & 19.75 & 22.66 & 23.57 & 23.66 & $23.71(29.13)$ & 76.29 \\
Control & 100.00 & 100.00 & 100.00 & 100.00 & 100.00 & $100.00(89.96)$ & - \\
Mean & 42.95 & 41.20 & 42.85 & 42.05 & 43.43 & & - \\
\hline
\end{tabular}

1999; Batta, 2003; Biswas, 1999; Harman and Kubicek, 1998; Dutta and Das, 1999; Omarjee et al., 2001). Other species of Trichoderma, namely T. pseudokoningii, T. koningii, $T$. hamatum, $T$. gamsii, $T$. atroviride, $T$. virens and $T$. viride have also been used as biological control agents to suppress the growth of various pathogenic fungi (Odebode, 2006; Ngullie et al., 2010; Jagtap et al., 2013; Shaikh and Nasreen, 2013).

A saprophytic strain of Pseudomonas syringae marketed under the trade name of Biosave ${ }^{\mathrm{TM}}$ provided biological control of grey mould, blue mould and Mucor rot on pear and apple fruits (Janisiewicz and Marchi, 1992; Jeffers and Wright, 1994; Mari et al., 2014). Another species of Pseudomonas namely Pseudomonas fluorescens, has been reported to control grey mould caused by Botrytis sp. (Mikani et al., 2008). Bacillus subtilis applied to wounded apples reduced fruit rot caused by $B$. cinerea, $A$. alternata, $P$. expansum and P. malicorticis (Leibinger et al., 1997; Wang et al., 2010). It has been reported that the post harvest brown rot of stone fruits can also be controlled by the application of Bacillus subtilis and Pseudomonas sp. (Pusey and Wilson, 1984; Smilanick et al., 1993).

\section{Conclusion}

The results of the present study indicate that isolate Trichoderma hamatum has great potential as antagonist of post harvest pathogens of apple and should be included in further investigations as potential microorganism for production of biofungicides intended to be used for protection of apple fruits from rot causing pathogens.

\section{References}

Agrios, G.N., 1997. Plant Pathology. $4^{\text {th }}$ Ed., Academic Press, New York, 703.

Al-Hindi, R.R., Al-Nazada, A.R., Mohamed, S.A., 2011. Isolation and identification of some fruit spoilage fungi: Screening of plant cell wall degrading enzymes. African Journal of Microbiology Research 5, 443-448.

Batta, Y.A., 1999. Biological effect of two strains of microorganisms antagonistic to Botrytis cinerea: causal organism of grey mould on strawberry. Natural Sciences 13, 67-83.

Batta, Y.A., 2003. Post harvest biological control of apple grey 
mould by Trichoderma harzianum Rifai formulated in an invert emulsion. Crop Protection 23, 19-26.

Biswas, K.K., 1999. Screening of isolates of Trichoderma harzianum Rifai for their relative biocontrol efficacy against Fusarium oxysporum f. sp. udum and Rhizoctonia solani Kuhn. Annals of Plant Protection Sciences 7, 125-130.

Calvente, V., Benuzzi, D., de Tosetti, M.I.S., 1999. Antagonistic action of siderophores from Rhodotorula glutinis upon the post harvest pathogen Penicillium expansum. International Biodeterioration and Biodegradation 43, 167-172.

Chan, Z., Qin, G., Xu, X., Li, B., Tian, S., 2007. Proteome approach to characterize proteins induced by antagonist yeast and salicylic acid in peach fruit. Journal of Proteome Research 6, 1677-1688.

Denis, C., Webster, J., 1971. Antagonistic properties of species group of Trichoderma production of volatile antibiotics. Transactiona of the British Mycological Society 57, 41-48.

Dutta, P., Das, B.C., 1999. Control of Rhizoctonia solani in soybean (Glycine max) by farmyard manure culture of Trichoderma harzianum. Indian Journal of Agricultural Sciences 69, 596-598.

El-Ghaouth, A., Wilson, C.L., Wisniewski, M., 2003. Control of post harvest decay of apple fruit with Candida saitoana and induction of defense responses. Phytopathology 93, 344-348.

Fiori, S., Scherm, B., Liu, J., Farrell, R., Mannazzu, I., Budroni, M., Maserti, B.E., Wisniewski, M.E., Migheli, Q., 2012. Identification of differentially expressed genes associated with changes in the morphology of Pichia fermentans on apple and peach fruit. FEMS Yeast Research 12, 785-795.

Granger, K., Horne, A.S., 1924. A method of inoculating the apples. Annals of Botany 38, 212-215.

Hafez, E.E., Meghad, A., Elsalam, H.A.A., Ahmed, S.A., 2013. Biological and molecular studies on Trichoderma viride - plant pathogenic fungi interactions. Journal of World Applied Sciences 21, 1821-1828.

Hamid, M.I., Hussain, M., Ghazanfar, M.U., Raza, M., Liu, X.Z., 2014. Trichothecium roseum causes fruit rot of tomato, orange and apple in Pakistan. Plant Disease 98, 1271.

Harman, G.E., Kubicek, C.P., 1998. Trichoderma and Gliocladium, Vol. 2. Enzymes, biological control and commercial application. Taylor and Francis, London 393.

Jagtap, G.P., Mali, A.K., Dey, U., 2013. Bioefficacy of fungicides, bio-control agents and botanicals against leaf spot of turmeric incited by Colletotrichum capsici. African Journal of Microbiology Research 7, 1865-1873.

Janisiewicz, W.J., Marchi, A., 1992. Control of storage rots on various pear cultivars with a saprophytic strain of Pseudomonas syringae. Plant Disease 76, 555-560.

Jeffers, S.N., Wright, T.S., 1994. Comparison of four promising biological control agents for managing postharvest diseases of apples and pears. Phytopathology 84, 1082.

Jurick, W.M., 2014. First report of Alternaria alternata causing post harvest decay on apple fruit during cold storage in Pennsylvania. Plant Disease 98, 690.

Leibinger, W., Breuker, B., Hahn, M., Mendgen, K., 1997. Control of postharvest pathogens and colonization of the apple surface by antagonistic microorganisms in the field. Phytopathology 87, 1103-1110.

Liu, J., Wisniewski, M., Droby, S., Vero, S., Tian, S., Hershkovitz, V., 2011. Glycine betaine improves oxidative stress tolerance and biocontrol efficacy of the antagonistic yeast Cystofilobasidium infirmominiatum. International Journal of Food Microbiology 146, 76-83.

Mari, M., Francesco, A.D., Bertolini, P., 2014. Control of fruit post harvest diseases: old issues and innovative approaches. Stewart Postharvest Review DOI: 10.2212/ spr.2014.1.1.

Marie-Jose, Cote, Marie-Claude, Tardif, Allison, J.M., 2004. Identification of Monilinia fructigena, M. fructicola, $M$. laxa and Monilia polystroma on inoculated and naturally infected fruit using multiplex PCR. Plant Disease 88, 1219-1225.

Mikani, A., Etebarian, H.R., Sholberg, P.L., Gorma, D.T., Stokes, S., Alizadeh, A., 2008. Biological control of apple grey mould caused by Botrytis mali with Pseudomonas fluorescens strains. Postharvest Biological Technology 48, 107-112.

Ngullie, M., Daiho, L., Upadhyay, D.N., 2010. Biological management of fruit rot in the world's hottest chilli (Capsicum chinense Jacq.). Journal of Plant Protection Research 50, 269-273.

Odebode, A.C., 2006. Control of post harvest pathogens of fruits by culture filtrate from antagonistic fungi. International Journal of Plant Protection Research 46, 1-6.

Omarjee, J., Hunter, C.H., Laing, M.D., 2001. Biocontrol of damping-off caused by Rhizoctonia and Pythium spp. with formulations of Trichoderma harzianum and Gliocladium virens. In: Abstracts of $39^{\text {th }}$ SASPP Congress. Greenway Woods, Nespriut, South Africa, 21-24 ${ }^{\text {th }}$ January, 2001.

Patale, S.S., Mukadam, D.S., 2011. Management of plant pathogenic fungi by using Trichoderma species. Bioscience Discovery 2, 36-37.

Pusey, P.L., Wilson, C.L., 1984. Post harvest biological control of stone fruit brown rot by Bacillus subtilis. Plant Disease 68, 753-756.

Shaikh, F.T., Nasreen, S., 2013. Biocontrol efficacy of Trichoderma koningii against some plant pathogenic fungi. Indian Journal of Research 2, 9-10.

Smilanick, J.L., Denis-Arrue, R., Bosch, J.R., Gonzalez, A.R., Henson, D., Janisiewicz, W.J., 1993. Control of postharvest brown rot of nectarines and peaches by 
Pseudomonas species. Crop Protection 12, 513-520.

Srivastava, M.P., Tandon, R.N., 1968. Influence of temperature on Botryodiplodia rot of citrus and sapodilla. Indian Phytopathology 21, 195-197.

Turechek, W.W., 2004. Apple diseases and their management. Diseases of Fruits and Vegetables 1, 1-108.

Utkhede, R.S., Rahe, J.E., 1983. Interactions of antagonists and pathogens in biological control of onion white rot. Phytopathology 73, 890.

Vico, I., Duduk, N., Vasic, M., Nikolic, M., 2014. Identification of Penicillium expansum causing postharvest blue mould decay of apple fruit. Pesticides and Phytomedicine 29, 257-266.

Vincent, J.H., 1947. Distortion of fungal hyphae in the presence of certain inhibitors. Nature 15, 580.

Wang, Y., Xu, Z., Zhu, P., Liu, Y., Zhang, Z., Mastuda, Y., Toyoda, H., Xu, L., 2010. Post harvest biological control of melon pathogens using Bacillus subtilis EXWB1. Journal of Plant Pathology 92, 645-652.

Wisniewski, M., Biles, C., Droby, S., McLaughlin, R., Wilson, C., Chalutz, E., 1991. Mode of action of the post harvest biocontrol yeast, Pichia guilliermondii. I. Characterization of attachment to Botrytis cinerea. Physiological and Molecular Plant Pathology 39, 245-258.

Xu, B., Zhang, H., Chen, K., Xu, Q., Yao, Y., Gao, H., 2013. Biocontrol of postharvest Rhizopus decay of peaches with Pichia caribbica. Current Microbiology 67, 255-261. 